\title{
Short Communication: Antibacterial activity of certain Saudi Arabian medicinal plants used in folk medicine against different groups of bacteria
}

\author{
ABDULLAH A. AL-GHANAYEM ${ }^{1}$, SANAD M. AL SOBEAI ${ }^{2}$, MOHAMMED S. ALHUSSAINI ${ }^{1}$, \\ BABU JOSEPH ${ }^{1, \bullet}$, ABDULMONEIM MOHAMMAD SAADABI ${ }^{1}$ \\ ${ }^{1}$ Department of Clinical Laboratory Sciences, College of Applied Medical Sciences, Shaqra University, Shaqra 11961, Kingdom of Saudi Arabia. `email: \\ bjoseph@su.edu.sa \\ ${ }^{2}$ Sajir College of Arts and Sciences, Shaqra University, Shaqra 11961, Kingdom of Saudi Arabia
}

Manuscript received: 7 November 2017. Revision accepted: 28 November 2017.

\begin{abstract}
Al-Ghanayem AA, Al Sobeai SM, Alhussaini MS, Joseph B, Saadabi AM. 2017. Antibacterial activity of certain Saudi Arabian medicinal plants used in folk medicine against different groups of bacteria. Nusantara Bioscience 9: 392-395. Medicinal plants from Saudi Arabia has been used in folk medicine for treatment of many diseases. The present research is on medicinal plants, which are locally available such as Acacia ehrenbergiana (Arabic: Salam) (Fabaceae), Calotropis procera (Arabic: Ausher) (Apocynaceae), Haloxylon salicornicum (Arabic: Rimth) (Amaranthaceae), Panicum turgidum (Arabic: Thuman) (Poaceae), Tamarix arabica (Arabic: Athal) (Tamaricaceae), Rhazya stricta (Arabic: Harmal) (Apocynaceae) Rumex vesicarius (Arabic: Humeid) (Polygonaceae) for antimicrobial activity by agar well diffusion method. Minimum Inhibitory Concentration (MIC) has been determined by broth micro dilution method. A. ehrenbergiana was active against Klebsiella pneumoniae. R. vesicarius and T. arabica showed antibacterial activity against Proteus vulgaris. C. procera showed a moderate inhibitory activity against the bacterial pathogens tested. $H$. salicornicum extract was more effective towards Gram-positive bacteria. However, other extracts such as $P$. turgidum and $R$. stricta were less active against both Gram-positive and negative bacteria tested. The results will be helpful in discovering new phytochemical components with antibacterial activity that can be used against multidrug-resistant bacterial strains.
\end{abstract}

Keywords: Acacia ehrenbergiana, antibacterial activity, Calotropis procera, medicinal plants, MIC, Rumex vesicarius

\section{INTRODUCTION}

Higher plants and their products have been used from ancient days for treating human diseases, and the usefulness of plant-based medicinal compounds gifted by nature is well understood. Some of these compounds have been supported for the design and development of synthetic drugs. Therefore, plants still have been a promising source of newer drugs (Veeresham 2012). There are a large number of unexplored plants and plant products with high therapeutic value. The antimicrobial activity of some medicinal plants present in the local area is not well explored. Meanwhile, some plants have been tested for their activities, but the reports are not well documented. Some of plant-based products from several geographical areas have been successfully entering the pharmaceutical industries because their phytochemical and biological studies have been conducted. There are many phytochemical components such as alkaloids, terpenes, flavonoids, glycosides, etc., showing a variety of pharmacological activities (Edeoga and Ikem 2002). On this basis, a number of locally available plants will be screened for both antibacterial and antifungal activities. A thorough investigation to evaluate the efficacy and safety of these herbal drugs will lead to development and identification of valuable compounds (Kesavan et al. 2007).
Development of antibiotic resistance has been increased worldwide. Because of the overdosage and unlimited usage of antibiotics for treatment of infections and preservation of food, bacterial and fungal pathogens have mutated and become multidrug-resistant (Nascimento et al. 2000). The growing concern of antimicrobial resistance becomes a global problem, and there is a necessary need to find out new potential antimicrobial agents which are safe and affordable to the public against multidrug-resistant strains of bacteria and fungi (Susana et al. 2007). The new antimicrobial agents can be used as synergetic drugs or in combination with conventional antimicrobial agents. There is an urgent need to develop novel molecules. Therefore, it is crucial to identify the antimicrobial potential of locally available plants and know the phytochemical composition to create a proper documentation. In the present study, some medicinal plants which are locally available in the region of Saudi Arabia such as Acacia ehrenbergiana (Arabic: Salam) (Fabaceae), Calotropis procera (Arabic: Ausher) (Apocynaceae), Haloxylon salicornicum (Arabic: Rimth) (Amaranthaceae), Panicum turgidum (Arabic: Thuman) (Poaceae), Tamarix arabica (Arabic: Athal) (Tamaricaceae), Rhazya stricta (Arabic: Harmal) (Apocynaceae) Rumex vesicarius (Arabic: Humeid) (Polygonaceae) were analyzed for antimicrobial activity. 


\section{MATERIALS AND METHODS}

\section{Plant materials}

Plants materials were collected from Shaqra area of Saudi Arabia and were authenticated by the Department of Botany, King Saud University, Kingdom of Saudi Arabia; voucher specimens were deposited at the department.

\section{Preparation of plant extracts}

The freshly collected aerial parts of the plants especially leaves were washed with running tap water and dried under shade. The materials were chopped and ground into coarse powder and extracted with methanol for $20 \mathrm{~h}$. The preparation was evaporated under vacuum to remove the solvents, and the extracts obtained were separately dissolved in Dimethyl sulfoxide (DMSO) to get a stock of $100 \mathrm{mg} / \mathrm{mL}$ concentration and kept in a refrigerator until used.

\section{Screening for antimicrobial activity}

The plant extracts were tested against different types of bacteria such as Pseudomonas aeruginosa, Proteus vulgaris, Salmonella typhi, Enterobacter cloacae, Klebsiella pneumoniae, Enterococcus faecalis, Escherichia coli, Bacillus cereus, Staphylococcus aureus and Streptococcus pneumoniae. The actively growing cultures of bacteria were inoculated into $4 \mathrm{~mL}$ of peptone water and incubated at $37^{\circ} \mathrm{C}$ for $4 \mathrm{~h}$. The turbidity of the growing cultures was adjusted to match 0.5 units of McFarland solution (Cheesbrough 2008). Agar well diffusion method was adopted to determine the antibacterial activity of extracts (Kavanagh 1972).

\section{Minimum inhibitory concentration}

Broth microdilution method was used to determine Minimum Inhibitory Concentration (MIC) for the active crude extracts against the test microorganisms. Test bacterial cultures $\left(100 \mu \mathrm{l}\right.$ of bacterial culture containing $10^{5}$ $\mathrm{CFU} / \mathrm{mL}$ ) were inoculated into tubes containing different concentrations of extracts $(75,37.5,18.8,9.4,4.7,2.4,1.2$, $0.6,0.3,0.15 \mathrm{mg} / \mathrm{mL}$ ) and incubated at $37^{\circ} \mathrm{C}$ for $24 \mathrm{~h}$. The values were determined by detecting the inhibition of visible growth in the culture tubes. Minimum Bactericidal Concentration (MBC) was assayed by sub-culturing the broth onto freshly prepared solid media and further incubated at $37^{\circ} \mathrm{C}$ for $24 \mathrm{~h}$. The lowest concentration of MIC tubes which did not show any growth of bacterial colonies was regarded as MBC (CLSI 2012).

\section{RESULTS AND DISCUSSION}

The methanol extracts of all the plants were tested for antibacterial activity against $P$. aeruginosa, $P$. vulgaris, $S$. typhi, E. cloacae, K. pneumoniae, E. faecalis, E. coli, B. cereus, $S$. aureus and $S$. pneumoniae. The previous study with $C$. procera has been shown that the plant has antibacterial and antiparasitic activities (Larhsini et al. 1999). In the present study, $R$. vesicarius and T. arabica at a concentration of $10 \mathrm{mg} / \mathrm{mL}$ showed inhibitory activity towards $P$. vulgaris. A. ehrenbergiana showed an antibacterial effect on $K$. pneumoniae at $10 \mathrm{mg} / \mathrm{mL}$. These results clearly show that high extract concentration has high antibacterial activity. Recently, Rahim et al. (2016) studied the antimicrobial activity of methanol extract of $A$. ehrenbergiana which showed a wide spectrum activity against bacterial isolates but a poor inhibitory activity on fungi. $R$. stricta showed relatively weak antibacterial activities against all Gram-negative bacteria tested. A recent study showed that $R$. stricta solvent extract has antimicrobial activity against Gram-negative and Grampositive bacteria and according to phytochemical analysis, the extract contains organic alkaloid (Raziuddin et al. 2016).

Table 2. Antibacterial activity of methanol extracts from different medicinal plants against Gram-positive bacteria *

\begin{tabular}{lcccc}
\hline \multicolumn{2}{c}{$\begin{array}{c}\text { Plant extract } \\
(\mathbf{m g} / \mathbf{m L})\end{array}$} & $\begin{array}{c}\text { Bacillus } \\
\text { cereus }\end{array}$ & $\begin{array}{c}\text { Staphylococcus } \\
\text { aureus }\end{array}$ & $\begin{array}{c}\text { Streptococcus } \\
\text { pneumoniae }\end{array}$ \\
\hline Rimth & 1 & 10 & 11 & 9 \\
Humeid & 10 & 17 & 18 & 18 \\
& 1 & 9 & 7 & 9 \\
Harmal & 10 & 12 & 11 & 10 \\
& 10 & 8 & 9 & 7 \\
Athal & 1 & 13 & 14 & 13 \\
& 10 & 12 & 8 & 8 \\
Salam & 1 & 8 & 15 & 17 \\
& 10 & 13 & 9 & 12 \\
Ausher & 1 & 10 & 13 & 7 \\
& 10 & 12 & 8 & 10 \\
Thuman & 1 & 11 & 9 & 7 \\
& 10 & 13 & 8 & 9 \\
\hline
\end{tabular}

Note: *values are means of 3 replicates (inhibition zone in $\mathrm{mm}$ )

Table 1. Antibacterial activity of methanol extracts from different medicinal plants against Gram-negative bacteria *

\begin{tabular}{|c|c|c|c|c|c|c|c|c|c|c|c|c|c|c|}
\hline \multirow{3}{*}{ Isolates } & \multicolumn{14}{|c|}{ Plant extract $(\mathrm{mg} / \mathrm{mL})$} \\
\hline & \multicolumn{2}{|c|}{ Rimth } & \multicolumn{2}{|c|}{ Humeid } & \multicolumn{2}{|c|}{ Harmal } & \multicolumn{2}{|c|}{ Athal } & \multicolumn{2}{|c|}{ Salam } & \multicolumn{2}{|c|}{ Ausher } & \multicolumn{2}{|c|}{ Thuman } \\
\hline & 1 & 10 & 1 & 10 & 1 & 10 & 1 & 10 & 1 & 10 & 1 & 10 & 1 & 10 \\
\hline Pseudomonas aeruginosa & 8 & 10 & 7 & 11 & 7 & 9 & 8 & 10 & 10 & 12 & 9 & 11 & 7 & 11 \\
\hline Enterobacter cloacae & 7 & 10 & 8 & 12 & 8 & 9 & 9 & 15 & 8 & 17 & 8 & 10 & 9 & 12 \\
\hline Enterococcus faecalis & 9 & 15 & 9 & 12 & 8 & 11 & 10 & 17 & 11 & 14 & 8 & 15 & 7 & 12 \\
\hline Escherichia coli & 7 & 9 & 8 & 13 & 7 & 10 & 8 & 13 & 7 & 11 & 7 & 11 & 8 & 12 \\
\hline Klebsiella pneumoniae & 7 & 11 & 8 & 15 & 9 & 10 & 11 & 17 & 10 & 18 & 7 & 12 & 6 & 13 \\
\hline Proteus vulgaris & 9 & 13 & 12 & 18 & 7 & 8 & 11 & 18 & 10 & 15 & 13 & 17 & 7 & 13 \\
\hline Salmonella typhi & 6 & 11 & 8 & 17 & 9 & 10 & 7 & 15 & 9 & 14 & 8 & 14 & 9 & 15 \\
\hline
\end{tabular}

Note: *values are means of 3 replicates (inhibition zone in $\mathrm{mm}$ ) 
Table 3. MIC and MBC values of methanol extracts of the selected plants against Gram-negative bacteria*

\begin{tabular}{|c|c|c|c|c|c|c|c|c|c|c|c|c|c|c|}
\hline \multirow{3}{*}{ Isolates } & \multicolumn{14}{|c|}{ Plant extract $(\mathrm{mg} / \mathrm{mL})$} \\
\hline & \multicolumn{2}{|c|}{ Rimth } & \multicolumn{2}{|c|}{ Humeid } & \multicolumn{2}{|c|}{ Harmal } & \multicolumn{2}{|c|}{ Athal } & \multicolumn{2}{|c|}{ Salam } & \multicolumn{2}{|c|}{ Ausher } & \multicolumn{2}{|c|}{ Thuman } \\
\hline & MIC & MBC & MIC & MBC & MIC & MBC & MIC & MBC & MIC & MBC & MIC & MBC & MIC & MBC \\
\hline Enterobacter cloacae & 18.8 & 37.5 & 18.8 & 37.5 & 37.5 & 75 & 37.5 & 75 & 37.5 & 75 & 9.4 & 37.5 & 9.4 & 18.8 \\
\hline Enterococcus faecalis & 9.4 & 18.8 & 9.4 & 18.8 & 9.4 & 37.5 & 9.4 & 37.5 & 9.4 & 18.8 & 9.4 & 18.8 & 37.5 & 75 \\
\hline Escherichia coli & 18.8 & 37.5 & 9.4 & 37.5 & 9.4 & 18.8 & 9.4 & 18.8 & 9.4 & 18.8 & 9.4 & 37.5 & 9.4 & 37.5 \\
\hline Klebsiella pneumoniae & 18.8 & 37.5 & 18.8 & 37.5 & 18.8 & 37.5 & 18.8 & 37.5 & 9.4 & 37.5 & 9.4 & 18.8 & 18.8 & 37.5 \\
\hline Proteus vulgaris & 18.8 & 37.5 & 4.7 & 9.4 & 9.4 & 18.8 & 9.4 & 18.8 & 37.5 & 18.8 & 37.5 & 18.8 & 9.4 & 37.5 \\
\hline Pseudomonas aeruginosa & 18.8 & 37.5 & 18.8 & 37.5 & 18.8 & 37.5 & 18.8 & 37.5 & 18.8 & 37.5 & 18.8 & 9.4 & 37.5 & 18.8 \\
\hline Salmonella typhi & 37.5 & 75 & 9.4 & 37.5 & 18.8 & 37.5 & 18.8 & 37.5 & 18.8 & 37.5 & 37.5 & 75 & 37.5 & 75 \\
\hline
\end{tabular}

Note: *values are in $\mathrm{mg} / \mathrm{mL}$

Table 4. MIC and MBC values of methanol extracts of the selected plants against Gram-positive bacteria*

\begin{tabular}{|c|c|c|c|c|c|c|c|c|c|c|c|c|c|c|}
\hline \multirow{3}{*}{ Isolates } & \multicolumn{14}{|c|}{ Plant extract $(\mathrm{mg} / \mathrm{mL})$} \\
\hline & \multicolumn{2}{|c|}{ Rimth } & \multicolumn{2}{|c|}{ Humeid } & \multicolumn{2}{|c|}{ Harmal } & \multicolumn{2}{|c|}{ Athal } & \multicolumn{2}{|c|}{ Salam } & \multicolumn{2}{|c|}{ Ausher } & \multicolumn{2}{|c|}{ Thuman } \\
\hline & MIC & MBC & MIC & MBC & MIC & MBC & MIC & MBC & MIC & MBC & MIC & MBC & MIC & MBC \\
\hline Bacillus cereus & 9.4 & 18.8 & 18.8 & 37.5 & 18.8 & 37.5 & 9.4 & 18.8 & 18.8 & 37.5 & 37.5 & 75 & 18.8 & 37.5 \\
\hline Staphylococcus aureus & 9.4 & 18.8 & 18.8 & 37.5 & 18.8 & 37.5 & 9.4 & 18.8 & 18.8 & 37.5 & 18.8 & 37.5 & 18.8 & 37.5 \\
\hline Streptococcus pneumoniae & 9.4 & 18.8 & 37.5 & 75 & 37.5 & 75 & 9.4 & 18.8 & 9.4 & 18.8 & 37.5 & 75 & 37.5 & 75 \\
\hline
\end{tabular}

Note: *values are in $\mathrm{mg} / \mathrm{mL}$

Table 5. Antibiotic sensitivity pattern shown by the test isolates *

\begin{tabular}{lccccc}
\hline $\begin{array}{c}\text { Bacterial } \\
\text { isolates }\end{array}$ & $\begin{array}{c}\text { Tetra- } \\
\text { cycline } \\
(\mathbf{3 0})\end{array}$ & $\begin{array}{c}\text { Erythro- } \\
\text { mycin } \\
(\mathbf{1 5})\end{array}$ & $\begin{array}{c}\text { Chlor- } \\
\text { amphenicol } \\
\mathbf{( 3 0 )}\end{array}$ & $\begin{array}{c}\text { Cipro- } \\
\text { floxacin } \\
\mathbf{( 5 )}\end{array}$ & $\begin{array}{c}\text { Genta- } \\
\text { micin } \\
(\mathbf{1 0})\end{array}$ \\
\hline B. cereus & 19 & 15 & 17 & 18 & 21 \\
E. cloacae & 14 & 17 & 18 & 16 & 19 \\
E. coli & 18 & 19 & 18 & 21 & 17 \\
E. faecalis & 20 & 21 & 22 & 19 & 20 \\
K. pneumoniae & 15 & 17 & 19 & 20 & 20 \\
P. aeruginosa & 15 & 14 & 12 & 11 & 17 \\
P. vulgaris & 20 & 24 & 21 & 24 & 20 \\
S. aureus & 20 & 24 & 20 & 18 & 17 \\
S. pneumoniae & 14 & 16 & 21 & 16 & 15 \\
S. typhi & 15 & 18 & 17 & 19 & 17 \\
\hline
\end{tabular}

Note: *values are inhibition zone in $\mathrm{mm}$

Calotropis procera showed moderate inhibitory activity. $C$. procera has been used to treat skin disorders, intestinal worms, etc. (Parrotta 2001). Anti-mycobacterial and antibacterial activities of $C$. procera against Treponema have been reported (Kew 1985). Furthermore, it has been used for the treatment of water at water purification plants to reduce the total viable count of microorganisms to an extent (Shittu et al. 2004). Antimicrobial activity of ethanolic extracts of $C$. procera has been shown to be effective against bacterial such as E. coli and fungal pathogens like Candida albicans (Kareem et al. 2008). Plant secondary metabolites were reported to play an essential role in plant physiology; have potential effect as antioxidants, anti-allergic anti-inflammatory anticancer and antihypertensive agents on a human body; and show antimicrobial activities as well (Daglia 2012). $P$. turgidum has been studied for its antimicrobial activity and found to be effective against C. albicans and Streptococcus pyogenes. Phytochemical analysis revealed that hot and cold extracts of $P$. turgidum consist of alkaloids, flavonoids, tannins and saponin compounds (El-Desoukey 2017). In the present study, however, only a moderate antibacterial activity was shown by $P$. turgidum against all Gram-negative bacteria tested. Minimum inhibitory concentration and minimum bactericidal concentration of the extracts was tested against Gram-negative bacteria, and the results are shown in Table 3.

Haloxylon salicornicum showed an antibacterial effect on all Gram-positive bacteria tested. The activity increases with the dose of the extracts. H. salicornicum has been reported for antidiabetic and antiseptic activity. Several alkaloids have been extracted from $H$. salicornicum (Benkrief et al. 1990). T. arabica also had considerable antimicrobial activity against Gram-positive strains. The antioxidant and antimicrobial activity of Tamarix sp. has been reported (Sultanova et al. 2001). However, both $H$. salicornicum and T. arabica did not inhibit the Gramnegative bacteria as strongly as they inhibited the Grampositive bacteria. Minimum inhibitory concentration was $9.4 \mathrm{mg} / \mathrm{mL}$ for $H$. salicornicum and T. arabica whereas, the minimum bactericidal concentration was $18.8 \mathrm{mg} / \mathrm{mL}$ (Table 4). Antibacterial activities of the most active plant extract were compared with that of the commercial antibiotics (Table 5). The results show that the selected plants have antimicrobial activities and further extended studies are needed pharmacological aspects and its phytochemical analysis. 


\section{REFERENCES}

Benkrief R, Brum-Bousquet M, Tillequin F, Koch M. 1990. Alkaloids and flavonoid from aerial parts of Hammada articulata ssp. Scoparia. Annales Pharmaceutiques Francaises 48: 219.

Cheesbrough M. 2008. Medical Laboratory Manual for Tropical Countries. Butterworth \& Co Ltd, Cambridge, UK.

CLSI. 2012. Methods for Dilution Antimicrobial Susceptibility Tests for Bacteria that Grow Aerobically, Approved Standard, 9th ed., CLSI document M07-A9. Clinical and Laboratory Standards Institute Wayne, Pennsylvania, USA.

Daglia M 2012. Polyphenols as antimicrobial agents. Curr Opin Biotechnol 23 (2): 174-181.

Edeoga HO, Ikem CL. 2002. Tannins, saponins and calcium oxalate crystals from Nigerian species of Boerhavia (Nyctaginaceae). S A J Bot 68 (3): 386-388.

El-Desoukey RMA. 2017. Phytochemical and antimicrobial activity of Panicum turgidum (Thummam) as a grazing herb against some animal pathogens. EC Microbiol 5 (1): 22-29.

Evans WC, Evans D, Trease GE. 2009. Trease and Evans Pharmacognosy. Saunders/Elsevier, Edinburgh.

Kareem SO, Akpan I, Ojo OP. 2008 Antimicrobial activities of Calotropis procera on selected pathogenic microorganisms. African J Biomed Res 11: 105-110.

Kavanagh F. 1972. Analytical Microbiology. Academic Press, New York, USA.

Kesavan S, Devarajan N, Chokkalingam M, Chinthambi V, Nandakumar N. 2007. Antibacterial, preliminary phytochemical and pharmacognostical screening on the leaves of Vicoa indica (L.) Iranian J Pharmacol Therapeut 6: 109-113.
Kew F. 1985. The useful plants of West Tropical Africa, Vol. (1) Families A-D Edition 2. In: Burkill HM (ed.). Royal Botanical Gardens, Kew.

Larhsini M, Oumoulid L, Lazrek HB, Wataleb S, Bousaid M, Markouk M, Jana M. 1999. Screening of antibacterial and antiparasidic activities of six Moroccan medicianal plants. Therapie 54 (6): 763-765.

Nascimento GGF, Locatelli J, Freitas PC, Silva GL 2000. Antibacterial activity of plant extracts and phytochemicals on antibiotic-resistant bacteria. Braz J Microbiol 31: 247-256

Parrotta JA. 2001. Healing plants of peninsular India. CAB International Wallingford, UK.

Rahim SAA, Almagboul AZ, Mohammed NEB. 2016. Antimicrobial activity of Croton zambesicus, Acacia ehrenbergiana and Fagonia cretica. Natl J Adv Res 2 (3): 16-20.

Raziuddin K, Mohammed N, Baeshen, Kulvinder S, Saini Roop S, Bora Ahmed M, Al-Hejin, Nabih A. Baeshen. 2016. Antibacterial activities of Rhazya stricta leaf extracts against multidrug-resistant human pathogens. Biotechnol Biotechnol Equip 30: 5, 1016-1025.

Shittu BO, Popoola TOS, Taiwo O. 2004. Potentials of Calotropis procera leaves for Wastewater treatment. Proceedings of the International Conference on Science and National Development, University of Agriculture, Abeokuta.

Sultanova N, Makhmoor T, Abilov ZA, Parween Z, Omurkamzinova VB, Atta-ur-Rahman, Iqbal Choudhary M. 2001. Antioxidant and antimicrobial activities of Tamarix ramosissima. J Ethnopharmacol 78: 201-205

Susana J, Moacir GP, Cláudio LD, Maria AR. 2007. Antifungal properties of plants used in Brazilian traditional medicine against clinically relevant fungal pathogens. Braz J Microbiol 38: 632-637.

Veeresham C. 2012. Natural products derived from plants as a source of drugs. J Adv Pharm Technol Res 3 (4): 200-201. 